Article

\title{
Emigration and the Transnationalization of Sending States' Welfare Regimes
}

\author{
Jean-Michel Lafleur ${ }^{1, *}$ and Inci Öykü Yener-Roderburg ${ }^{2,3,4}$ \\ ${ }^{1}$ Centre for Ethnic and Migration Studies, University of Liège, Belgium \\ 2 Department of Sociology of Migration, TU Dortmund, Germany \\ ${ }^{3}$ Institute of Turkey Studies, University of Duisburg-Essen, Germany \\ ${ }^{4}$ DRES Research Center, University of Strasbourg, France \\ * Corresponding author (jm.lafleur@uliege.be)
}

Submitted: 16 July 2021 | Accepted: 4 February 2022 | Published: 22 March 2022

\begin{abstract}
How does emigration affect sending states' welfare policies? Existing migration literature has identified numerous political, economic, and institutional variables that influence sending states' approaches towards emigrants' welfare. However, this literature has neglected broader processes of social transformation in sending states. Using the concept of welfare regime transnationalization, we show more precisely how emigration transforms welfare regimes in their functional, distributive, normative, and politico-institutional dimensions. This process is nonetheless strongly constrained by domestic politics. To illustrate our analytical framework, we discuss the transnationalization of health policies in Turkey and Mexico.
\end{abstract}

\section{Keywords}

diaspora; emigration; immigration; health; Mexico; transnationalization; Turkey; welfare regime

Issue

This article is part of the issue "Transnational Social Protection: Inclusion for Whom? Theoretical Reflections and Migrant Experiences" edited by Elisabeth Scheibelhofer (University of Vienna), Emma Carmel (University of Bath), and Anna Amelina (University of Cottbus).

(C) 2022 by the author(s); licensee Cogitatio (Lisbon, Portugal). This article is licensed under a Creative Commons Attribution 4.0 International License (CC BY).

\section{Introduction}

How does emigration affect sending states' welfare regimes? In spite of the numerous controversies around issues of welfare and migration that take place across the world, existing scholarship has not yet proposed an answer to this particular question. As we show in the first part of this article, social policy and migration scholars have developed separate discussions on the migrationwelfare nexus. The social policy literature has looked into how migration shapes welfare reforms but looks primarily at policy restrictions faced by immigrants in their country of residence. The migration literature, and in particular the diaspora and transnationalism literature, highlights emigrant agency in home country politics.
It nonetheless largely neglects that welfare policies concerning citizens abroad are also driven by institutional, normative and political variables.

To overcome the limits of existing scholarship, we propose in the second part of this article to combine these two bodies of literature. More precisely, we build on the argument of Ferrera et al. (2000) according to which deep societal transformations in European welfare states push them to "recalibrate," that is, to reform in their distributive, functional, normative, and politicoinstitutional dimensions. Adjusting this concept with the input of migration scholarship, we propose the analytical concept of welfare regime transnationalization, which we define as processes of change in discourses, social policies, and institutional responsibilities implemented 
by welfare states to respond to the new social risks that mobile populations and their immobile relatives face due to emigration.

In the third part of the article, we apply our analytical framework to recent health policy reforms in Mexico and Turkey that highlight the role of emigration in welfare reforms. To do so, we also rely on original qualitative data collected by the authors in the two countries. Overall, our case studies offer empirical evidence of the relevance of the concept of "welfare regime transnationalisation" as an analytical framework to study emigrants' impact on homeland welfare regimes. However, the case studies also highlight how domestic politics hinder the full transnationalization of welfare regimes.

\section{Combining Social Policy and Migration Studies Approaches to Welfare State Reforms}

Coverage of individuals against social risks by nationally institutionalized welfare systems has long been perceived as a core foundation of citizenship associated with full membership in a national society (Faist \& Bilecen, 2014; Marshall, 1964). This vision is however contested by immigration as it historically triggered debates within polities about who is a legitimate receiver of statesponsored solidarity beyond the sole criteria of nationality. In the European context, already in the immediate post-war period, several North-Western welfare states explicitly included access to welfare policies in the labour recruitment agreements they signed with Mediterranean states. Far from the predominantly negative tone that characterizes contemporary debates on welfare and migration, migrants were therefore once perceived as both needed contributors to European welfare systems and legitimate beneficiaries of welfare policies. This rationale of decoupling rights from nationality (see Soysal, 1994) also guided the EU integration process from its inception as it explicitly recognized the need for taking the portability of welfare entitlements into account to encourage workers' cross-border mobility. However, in spite of this evolution, European welfare states maintained that access to social rights had to still be primarily determined by a direct relationship between individuals and nation-states (Maas, 2007). This explains why in the context of the 2008 financial crisis and later the 2015 "refugee reception crisis," EU member states have been able to adopt a series of restrictions to mobile individuals in their welfare legislation (e.g., the removal of residence permits to EU citizens on benefits) to curb specific flows of undesirable migrants (Lafleur \& Mescoli, 2018; Pennings \& Seeleib-Kaiser, 2018).

While numerous policy-makers across Europe and North America are quick to point out the centrality of immigration as a factor justifying welfare states reforms, the scientific literature offers a much more nuanced picture of the link between the two phenomena. As noted by Van Kersbergen (2002), social science disciplines have approached the welfare state differently. Economists and sociologists have traditionally looked at the welfare state as an independent variable and therefore try to determine how policies generate certain social and economic outcomes. Political scientists, on the other hand, treat the welfare state as a dependent variable and are accordingly more interested in explaining why certain policies are adopted and how they vary across nations.

In the abundant literature that seeks to explain welfare state reforms, immigration is rarely a central explanatory variable. In her review of existing evidence in the field of economics on the association between immigration and welfare effort, Fenwick (2019, p. 360) noted the influence of migration on welfare state effort "is complex and likely to be influenced and mediated by a number of factors." Of course, migration has long been identified as an underlying factor that accompanies macro societal transformations which themselves trigger welfare reforms. Scholars such as Wilensky and Lebeaux (1965) for instance focused on the role of industrial development while Pampel and Williamson (1989) identified demographic changes as explanatory variables. In this sense, while the link is rarely explicitly made, scholarship on welfare state reforms is much more related to existing migration theories than one could expect at first sight. To illustrate this point one can look at the new economics of labour migration (Stark \& Bloom, 1985) according to which migration occurs when households seek to minimize risks of social exclusion by diversifying the type of economic activities in which their members engage. According to this theory, migration can thus be partly explained by the immigrants' country of origin welfare systems that does not act as a necessary buffer to prevent people from migrating (Kureková, 2013).

Scholars who have focused on the politicization of welfare reforms since the 1970s insist that, beyond these macro-evolutions, "politics matter." In other words, welfare state reforms cannot be disconnected from party politics (Castles, 1999), the logic of elections but also from welfare institutions themselves that promote pathdependence through their capacity to block reforms (Pierson, 1994). As immigration progressively became one of the most contentious topics in European and North American politics, a political-electoral approach potentially places immigrants at the centre of welfare state reforms. Indeed, parties concerned with their electoral performance do have to take a position on immigrants' access to social protection systems. Those debates are indeed frequently overshadowed by welfare chauvinistic positions and the perception that generous welfare policies necessarily lead to increased immigration-a position that some pundits derive from Borjas' (1998) famous "welfare magnet hypothesis." Nowadays, arguments about the fiscal impact of migration are still frequently voiced in debates around welfare policy reforms to restrict immigrants' access to public funds (Deacon \& Nita, 2013).

Overall, while the idea that "politics matter" is essential to understand contemporary debates on welfare and 
migration, it does not consider immigrants as agents in welfare state reform but merely as one among several variables that may contribute to the outcome of welfare state reforms. This way of conceptualizing the role of immigrants in welfare strongly diverges from recent socio-anthropological scholarship on migration and social protection. Indeed, migration scholars primarily interested in the transnational dimension of social protection practices and policies have examined the role of immigrants as formal and informal social protection providers in countries of origin (see, for instance, Mingot \& Mazzucato, 2017), their experience with accessing welfare entitlements across borders (see, among others, Amelina et al., 2019) and the normative debates associated with these questions (Faist, 2019).

As the literature on immigrant transnationalism has evolved in recent years, a number of scholars have examined policies adopted by sending country governments by which they seek to engage with citizens abroad, their descendants and/or specific ethnic groups that these states acknowledge as being members of the polity independently of their nationality (Collyer, 2013; Delano, 2009; Gamlen, 2019). Such state engagement is often presented as a natural consequence of the growing instrumental use of emigrants for economic or political purposes (Lafleur, 2013). While some attempts have been made to examine the role of emigrants in their homelands' electoral and nationality policies, the actual influence of diasporas on the design of home country social policies is still largely unknown. At the same, overemphasizing the economic and electoral weight of diasporas on their homelands may lead to neglecting the influence of other home country actors. Similarly, pathdependency and institutional resistance may limit diaspora agency in processes of policy reform.

Overall, existing scholarship, whether starting from the welfare policy approach or the migration and development approach, has not yet successfully identified the mechanisms by which immigrants as agents in policy-making processes can shape the outcome of welfare reforms in their home country. In the remaining parts of this article, we, therefore, develop an analytical framework that builds on these two bodies of literature and then proceed to examine two case studies on the impact of emigrants on Turkey and Mexico's health policies.

\section{From Recalibration to Transnationalization of Sending States' Welfare Regimes}

A major challenge in attempting to develop a conceptual framework to analyse the impact of emigration on sending states' welfare regimes is that the characteristics of welfare states across the world vary substantially. The literature on welfare states' evolution has paid significant scholarly attention to categorizing them according to different regimes. In this regard, Esping-Andersen's (1990) seminal work that stressed the role of decom- modification and defamiliarization in the development of welfare states in the Global North has triggered numerous reactions. Several scholars have indeed attempted to refine typologies by paying specific attention to unexamined areas such as Southern Europe (Ferrera, 1996). Similarly, scholars from the Global South and international development scholars have also questioned the limits of trying to apply the regime approach to middleand low-income countries. For instance, existing typologies have not paid sufficient attention to the role of informal employment as a decisive feature that creates significant segmentation in access to state-sponsored social protection (Barrientos, 2004). Related to this, a Western approach to welfare regimes therefore also tends to undermine the role of non-state actors (such as churches or NGOs) that are key players in the provision of social protection in the Global South (Martínez Franzoni, 2018; Wood \& Gough, 2006).

Taking these specificities into consideration, we propose to start from the social policy literature and in particular the concept of recalibration (Ferrera et al., 2000) that was developed in the European context as both a heuristic and prescriptive tool. Recalibration suggests that long-term and deep societal transformations such as "international competitiveness, the transformation of working life, the demise of traditional family structures, [and] demographic ageing and fiscal austerity" affect the "welfare architecture" of European welfare states (Hemerijck, 2006, p. 8).

According to these scholars, welfare states' recalibration occurs at four different levels. First, functional recalibration consists of the welfare state transformations required to adjust to the news social risks that arise from the post-industrial society. The authors mention technological changes or the feminisation of the labour force as examples of factors that require policy adjustments such as training or child care programmes. Second, distributive recalibration has to do with the fact many new social risks primarily affect certain cohorts more than others, such as young people and young families. These groups lack political capital compared to other parts of the population and therefore require additional attention. Distributive recalibration, therefore, stresses the need for "rebalancing of social protection provisions across policy clienteles, stakeholder interests, and public and private resources" (Hemerijck, 2006, p. 10). Third, normative recalibration concerns the norms and values that policy-makers need to put forward to justify reforms addressing these new social risks and redistributing the balance of power towards disadvantaged groups. It, therefore, has to do with the discourses that legitimize social policy reforms. Fourth, institutional recalibration refers to deeper structural changes within Welfare States that are deemed necessary to address new social risks and protect disadvantaged groups. It has precisely to do with "the design of institutions, levels of decision-making, and social and economic policy governance, including the separate and joint responsibilities 
of individuals, states, markets and families" (Hemerijck, 2006, p. 13).

While the concept of recalibration proves invaluable to approach the transformation of European welfare states, it has limits inherent to the European and social policy contexts in which it was developed. Beyond the limits that Eurocentric approaches already expressed above, we argue that-in line with other social policy works discussed above-this approach also underconceptualizes the effect of migration on social policy changes. In the remaining paragraphs and adapting the four dimensions of the concept of calibration, we, therefore, suggest looking at the effect of outward mobility on the welfare architecture of the states of origin. To this end, we propose to look at welfare regime transnationalization, which we define as processes of change in discourses, social policies and institutional responsibilities implemented by welfare states to respond to the new social risks mobile and immobile populations face due to emigration. More precisely, we call these processes "transnationalisation" rather than "internationalization" because this process goes further than international cooperation between nation-states (e.g., via the signature of international social security agreements). On the part of the sending countries' welfare systems, transnationalization represents an explicit acknowledgement that the physical presence of individuals on the national territory is no longer a requirement to benefit from state-sponsored solidarity.
Welfare regime transnationalization, we argue, is a process that has four dimensions (see Table 1). The first two dimensions are identifiable at the discursive level. It consists, first, in the identification by political elites in public discourses of the necessity for the welfare state to include the category of emigrants and/or their relatives among the beneficiaries of its policies and programmes (distributive transnationalization). Second, functional transnationalization occurs concomitantly in stressing that this new category of beneficiaries of welfare support requires ad hoc policy responses because their needs fall outside of the traditional realm of welfare policies. In this dual process of legitimation, the economic importance of the diaspora and the remittances they send, the emotional burden that emigration represents or the impact absence has on relatives who stayed behind serve to justify the need for social policy reforms. In this sense, the ability of citizens abroad to mobilize and voice on the home country political stage their shared concerns about their social protection concerns is critical. The last two dimensions of welfare regime transnationalization concern the materialization of these discursive elements into actual policies. Normative transnationalization refers to social policy adjustments designed to address new cross-border social risks for groups identified as requiring the protection of the homeland. Beyond a mere service provided by consular authorities, normative transnationalization rather refers to the adjustments of existing social policies to take into account the

Table 1. The four dimensions of welfare regime transnationalization.

\begin{tabular}{llll}
\hline & Definition & Case study 1: Turkey & Case study 2: Mexico \\
\hline Distributive & Identification of new groups & Retired return migrants & Mexican families with a \\
transnationalization & that require the welfare state's & and emigrants visiting the & breadwinner abroad and \\
& protection independently of & homeland for a short & return migrants \\
& their primary place of & period &
\end{tabular}

$$
\text { residence }
$$

Functional

transnationalization

Identification of new social risks triggered by international migration that require home country intervention

Normative transnationalization

Politico-institutional transnationalization cross-border social risks for
Social policy adjustments designed to address new groups identified as requiring the protection of the homeland

Redistribution of institutional responsibilities and/or the emergence of new actors to implement cross-border social policy adjustments
Difficulty to use host country public health insurance for emigrants during temporary visits and/or upon return to the homeland

Agreement between Turkish and welfare authorities of different EU member states to facilitate public health insurance intervention

Increased administrative cooperation of Turkish welfare authorities with European counterparts
Difficulty to access Mexico's public health insurance for families split across borders

Policy enabling emigrants to register non-migrant dependents to Mexico's universal health coverage

Posting of health ministry civil servants in consulates 
specific needs of mobile populations and/or their nonmobile relatives. One critical element about these policy adjustments is that it is not necessarily concerned with the ability of the reform to respond to the actual need that was identified. It can also be adopted to symbolically respond to the pressure of the emigrant population. Fourth, politico-institutional transnationalization has to do with the redistribution of institutional responsibilities and/or the emergence of new actors to implement cross-border social policy adjustments. The degree to which traditional institutions in charge of welfare policies on the national territory are involved in the implementation of policies that target emigrants and their dependents is, accordingly, an indication of how much the infrastructure that upholds the welfare state is itself transnationalized.

\section{Empirical Evidence of the Transnationalization of Health Policies in Turkey and Mexico}

In this section, we discuss two health reforms in Turkey and Mexico that highlight processes of welfare regime transnationalization. These two cases were selected because of similarities in their emigration and socioeconomic profiles. Looking at their migratory profiles, both states have a large diaspora, amounting - at the beginning of the 21st century-to 11 million people in the case of Mexico and 2.5 million individuals in the case of Turkey, according to the approach of the OECD (2011) measuring diasporas. Similarly, as we shall see below, both Mexico and Turkey have a high level of institutionalization of their relations with the diaspora via dedicated ministries and/or agencies, as well as voting rights and programmes to support diaspora organizations in destination countries. In other words, unlike smaller, more fragmented and less organized diasporas, both the Mexican and Turkish diasporas have a demonstrated capacity to dialogue with homeland authorities; including on matters of social protection. From a socio-economic viewpoint, both states are middleincome countries who are members of the OECD, unlike most other large emigrant sending states. In addition, as noted by Özel and Parrado (2020) both states share "parallel legacies of highly stratified Bismarckian conservative welfare states." In both cases, their welfare regimes expanded in the 1990s as they integrated more deeply into regional and global economies. These two characteristics - their socio-economic status and similar evolution of their welfare regimes-entail that both states had comparable capacities to react to the pressure of the diaspora claiming inclusion in their homeland's health reforms.

\subsection{Turkey: Transnationalization of Welfare Policies for Electoral Gains?}

Turkey's engagement in favour of the social welfare of its citizens abroad started as early as the 1960s with the signature of bilateral or multilateral agreements to protect guest workers who moved to Western Europe (Sirkeci, 2003). These agreements - the first of which was signed in 1961 with West Germany-focused primarily on return migrants and the pension rights of migrant workers. In this initial period, the attitude of Turkish authorities in the area of social welfare can be characterised as mostly passive with few exceptions. In the area of citizenship, on the contrary, Turkish authorities have clearly entered a phase of distributive transnationalization in the 1990 s by identifying citizens abroad as a category that required specific attention. The 1995 citizenship law, for instance, enabled former Turkish citizens who had to renounce their citizenship to access naturalization in their country of residence to access a special citizenship status that came with electoral rights as well as the right to retire in Turkey (Çağlar, 2004; McFadden, 2019).

The first electoral victory of the Justice and Development Party (Adalet ve Kalkınma Partisi [AKP]) in 2002, has given a new turn to Turkey's diaspora engagement (Arkilic, 2021). It is particularly visible at the institutional level; with institutions being created (i.e., the Office for the Turks Abroad and Related Communities [YTB]) or expanded (i.e., consular network) and non-state organizations receiving public support (i.e., the Turkish-Islamic Union for Religious Affairs [DITIB]) (Adamson, 2019; Aydin \& Østergaard-Nielsen, 2020; Yanasmayan \& Kaşlı, 2019; Yener-Roderburg, 2020). In the area of welfare mainly on health-related matters, all these institutions have also become informal counselling bodies. With the support of the Ministry of Culture and Tourism of Turkey, the YTB, for instance, offers seminars and workshops in Turkish missions abroad to inform the diaspora members about their right to social protection (see YTB, 2022). Similarly, the unofficial European branch of the Presidency of Religious Affairs, the DITIB, launched family and psychological counselling services in 2009 (see DITIB, 2009). This development cannot be disconnected from the expansion of the emigrant franchise, which, since 2012, has increased the population of external voters to over three million citizens, most of whom favour the AKP (Umpierrez de Reguero et al., 2021). For this reason, it appears that AKP-linked organizations have a clear incentive-particularly in Germany, where its diaspora is concentrated-to offer services in the area of welfare but also services related to education and religious affairs.

In the area of social protection, in particular, the most innovative programme launched by Turkish authorities under the AKP government is the Overseas Provision Activation and Health System (YUPASS), which came into force in 2014. In a clear sign of distributive transnationalization of the Turkish welfare regime, YUPASS was introduced under the justification of responding to the health care needs of the diaspora during their visits to Turkey. YUPASS initially appeared as a unique Turkish 
health service system that enables blue card or Turkish citizenship holders and their family members who are permanent residents in selected EU member states to access Turkish health services, in a similar fashion to tax-paying residents during short visits or long term stays in Turkey. The first agreement was signed with Germany in 2014, followed by others in 2017 with Belgium, Austria, France, and the Netherlands, and more recently Cyprus, North Macedonia, Romania, Albania, Bosnia-Herzegovina, Czechia, and Luxembourg. To access this benefit-which frees eligible individuals of the obligation to subscribe to travel insurance-beneficiaries are required to submit a valid social security document from their host country health care public insurance and register it, upon their arrival in Turkey, at the social security offices. YUPASS is therefore a clear indication of a form of institutional transnationalization of the Turkish welfare regime since it requires cooperation between Turkish and foreign welfare authorities. The ability for individuals to access care and medicine under this system without having to put the money upfront, however, was terminated on 1 December 2019 under the economic and currency crisis that placed a heavy toll on the country's public finances. Following reform, individuals now have to pay upfront for care and medicine and apply for reimbursement upon their return to their country of residence (unless they seek emergency medical attention). Considering that emergency care had always been freely accessible to visitors, the reform made YUPASS significantly more burdensome and less attractive for the diaspora.

Overall, YUPASS is a policy that has received significant media attention in Turkey and among the diaspora upon its introduction and it was recurrently raised during the 2015 and 2018 electoral campaigns as a symbol of the authorities' concern for the diaspora. On the contrary, the 2019 reform that rendered YUPASS significantly less attractive for its target group was barely advertised. These elements indicate that there is a strong symbolic if not instrumental dimension within Turkey's process of transnationalization of its welfare regime.

\subsection{Mexico: Institutional Limitations in the Transnationalization of Welfare Regimes}

Mexico's engagement with its diaspora in the area of welfare is not a recent phenomenon but is however directly related to the transformation of the country's political regime. The coming to power of Vicente Fox in 2000, after 71 years of rule by the Institutional Revolutionary Party, marked a paradigm shift. After decades of distrust towards citizens abroad, Fox engaged in a process of distributive transnationalization, developing a new narrative according to which the physical absence of citizens from the national territory was no longer a sufficient condition to exclude nationals from public policies. Similarly, Fox initiated a process of institutional transnationalization that progressively led to an expan- sion of its consular network and the creation of a dedicated public institution to support its diaspora called the Institute of Mexicans Abroad (see, among others, González Gutíerrez, 2003).

Enhancing the diaspora's access to welfare and, in particular, improving undocumented migrants' access to health services in the US has occupied a good share of the authorities attention over the years. For over a decade, Mexican authorities have indeed been conducting information campaigns in the US intending to raise health awareness among the migrant population (i.e., "bi-national health weeks") and created "health windows" in consulates to inform documented and undocumented migrants about their options to access healthcare in the US (Delano, 2018). These different Mexican initiatives also illustrate one of the major institutional limitations of Mexico's attempt to transnationalize its welfare regime: Unlike Turkey, Mexican authorities can only count on the limited cooperation of host country authorities (in this case, the US). At the state level, some notable initiatives have been taken to address the specificity of Mexican immigrants' health needs. In California, for instance, the 1998 Knox-Keene Act allows employers to purchase insurance coverage for their employees who live in Mexico or prefer to use health services in that country (see Vargas-Bustamente, 2008). On the national level, however, the US Federal Government has appeared largely uninterested in cooperating with Mexico in the area of welfare since the end of Bracero programme in 1964, which had consisted of a series of diplomatic agreements between the US and Mexico providing for short-term labour contracts to Mexican farm and railroad workers. They included provisions aiming at guaranteeing decent labour conditions as well as an obligation to US employers to withhold $10 \%$ of their wages and deposit it on a bank account to be later transmitted to Mexican banks for future access by the workers (see Driscoll de Alvarado, 2003). One element that supports this view of a lack of interest on the part of US federal authorities is the fact that a social security totalization agreement-coordinating coverage for workers who have a career split between two states-has been awaiting ratification by the US since 2004. This lack of engagement from the receiving country authorities stands in major contrast to the Turkish case study discussed above.

The above-mentioned Mexican initiatives in the area of immigrant health are ad hoc programmes run autonomously by the Ministry of Foreign affairs. On the contrary, the creation in 2005 of a universal health programme for residents through a prepaid and subsidized plan called seguro popular ("people's insurance") appears as the first real attempt at transnationalizing the Mexican welfare regime. This plan-designed to limit out-of-pocket payments-guarantees basic healthcare (medical, surgical, pharmaceutical, and hospital services) to millions of non-migrant Mexicans who did not previously have access to health insurance through work. 
In a clear acknowledgement of the interdependence between emigrants and their non-migrants dependents, the policy explicitly allowed heads of households in Mexico to register other family members even in their absence. Such possibility entailed, for instance, that spouses living in Mexico were able to register their partners and therefore ensure their immediate access to healthcare upon visit or return (Vargas-Bustamante et al., 2012). Similarly, grandparents were given the possibility to register their grandchildren in the case both parents had migrated. This policy that granted citizens abroad similar attention to residents in a critical public health policy indicates the clear distributive transnationalization (i.e., the willingness to target a new group of beneficiaries) of the Mexican welfare state.

This process further developed with the signing of an agreement between the Foreign Affairs Ministry (i.e., the Institute for Mexicans Abroad) and the Health Ministry by which immigrants became able to pre-register themselves as well non-migrant relatives to this plan in Mexican consulates and health windows (Smith et al., 2020). The rationale behind this agreement was that immigrants have a strong influence on relatives in the home country and have a stake in registering them because they tend to use remittance money to cover their health costs (Frank et al., 2009). With this development, the institutional transnationalization of Mexico's welfare regime became evident at two different levels. First, this policy entailed that Mexican welfare institutions were explicitly engaging with non-residents. Second, the consular network-an actor that was traditionally not involved in social policies-was given a critical role in the implementation of one of the country's biggest social programmes in recent history.

Despite the incentive for Mexican immigrants and their relatives to join seguro popular, the initiative of involving diaspora to expand universal health coverage in Mexico was relatively short-lived. Indeed, the possibility to pre-register from abroad no longer exists, but a more limited cooperation-focused on deported migrants only-continues to occur between the Foreign Affairs and the Health Ministry. One element that contributed to the termination of the programme, we argue, is that the process of transnationalization of Mexico's seguro popular policy was incomplete. Indeed, the policy acknowledged the existence of new social risks (functional transnationalization), the need to address the welfare needs of non-residents and their immobile relatives (distributive transnationalization), and was accompanied by discourses and policies that justified emigrant involvement to improve the coverage of their non-emigrant dependents (normative transnationalization). Institutional transnationalization was, however, left incomplete. Registration to seguro popular from abroad required important financial and human resources, which triggered institutional competition between Mexican health authorities and the Foreign Affairs Ministry. For health authorities, engaging with nationals abroad when their core mission is to deal with the resident population is, therefore, a trade-off between the potential gains that emigrant involvement may entail in terms of improvement of the previously excluded (migrant and non-migrant) population and the cost or signing partnerships and running promotional campaigns outside of the territory. For the Foreign Affairs Ministry, on the other hand, delegating part of the relation with the diaspora to another ministry and allowing these actors to operate in consulates when the Foreign Affairs Ministry had a historical monopoly in terms of diaspora relations proved to be sensitive.

\section{Conclusion: Emigrant Agency, Domestic Politics, and the Limits of Welfare Regime Transnationalization}

Our two case studies have revealed the interest of approaching the issue of sending states' engagement for the well-being of their citizens abroad from a welfare regime perspective. Despite the similarities in their emigration profile, socioeconomic status, and historical evolution of the welfare regimes that justified the selection of these two cases, our discussion showed a significant difference between the two cases: the role of destination country authorities. Turkey had been able to implement social security agreements with a number of European destination countries which enabled it to offer-for a limited period-an extensive form of health coverage for which it could count on the financial contribution of partner countries. Mexico, on the contrary, has had to implement its health reform without the cooperation of the US federal authorities. This difference in engagement of receiving state authorities, we argue, have had financial and legal implications that significantly influenced the type of welfare policies for citizens abroad that sending states can support.

The analytical framework developed in Section 2 of the article allowed us to identify in the two case studies how emigration has become an integral part of discourses, policies and institutions in middle-income sending states. However, as our data did not aim to establish a direct causal link between emigration and welfare reforms, our findings do not allow us to conclude that emigration is the decisive factor in the reform that we analysed. Indeed, our two cases showed how, in two states that had experienced large emigration for several decades, it is only with the coming to power of political parties wishing to capitalize on the emigrant population that the welfare regime started to go through a process of transnationalization across several of its dimensions. In this sense, our article supports a "politics matter" approach to welfare state reform: It highlights how domestic politics and more precisely expected political gains encourage reforms. Similarly, the fact that the two reforms we studied-YUPASS and seguro popular-were downsized after an initial phase of expansion towards citizens abroad hints at the symbolic, if not instrumental, motives that guide political actors in the 
transnationalization of welfare regimes: a finding that scholars interested in diaspora engagement policies have already hinted at. Overall, our empirical findings, therefore, serve to recommend including a "transnationalization of welfare regimes" approach to the study of welfare reform of migrant-sending countries as it allows the identification of variables that are traditionally neglected in welfare literature.

Less expectedly, the two cases also showed how processes of welfare regime transnationalization are intertwined with broader evolutions of welfare policies worldwide. In line with the global trend of increasing individual responsibility in welfare policies, both the Turkish and Mexican policies placed the onus of obtaining health coverage in the homeland on individual emigrants. Indeed, independently of the fact that emigrant agency in the area of welfare may be limited by legal, educational, or financial barriers, the benefit of welfare regime transnationalization is far from universal but rather limited to those who can comply with bureaucratic requirements.

However, independently of the fact that the two reforms we studied were short-lived in their most "generous" version, our analytical framework allows us to conclude that they created precedents that made lasting marks in their respective countries' welfare systems at three levels. First, non-residents are now deemed legitimate beneficiaries of state-sponsored solidarity (distributive transnationalization). Second, this population is acknowledged to have specific needs to be addressed beyond the host state's responsibilities (functional transnationalization). Third, there exist discourses and norms to justify these interventions (normative transnationalization). Lastly, our analytical framework revealed that institutional transnationalization remains one of the major hurdles to the transnationalization of welfare regimes. Indeed, path-dependency of welfare institutions unaccustomed to dealing with cross-border issues and the potentially diverging interests of home and host country welfare institutions place emigrants in the precarious position of seeing their newly gained benefits removed, improperly implemented or even duplicated with host country benefits.

\section{Acknowledgments}

Results presented in this article were collected in the framework of the project Migration and Transnational Social Protection in (Post)Crisis Europe (MiTSoPro), financed by the European Research Council (Starting Grant No. 680014). The authors wish to thank Evelyn Astor and Sousso Bignandi for their comments and editing suggestions on earlier versions of this article.

\section{Conflict of Interests}

The authors declare no conflict of interests.

\section{References}

Adamson, F. B. (2019). Sending states and the making of intra-diasporic politics: Turkey and its diaspora(s). International Migration Review, 53(1), 210-236.

Amelina, A., Carmel, E., Runfors, A., \& Scheibelhofer, E. (Eds.). (2019). Boundaries of European social citizenship: EU citizens' transnational social security in regulations, discourses and experiences (Vol. 1). Routledge.

Arkilic, A. (2021). Explaining the evolution of Turkey's diaspora engagement policy: A holistic approach. Diaspora Studies, 14(1), 1-21.

Aydin, S., \& Østergaard-Nielsen, E. (2020). Diaspora policies, consular services and social protection for Turkish citizens abroad. In J.-M. Lafleur \& D. Vintila (Eds.), Migration and social protection in Europe and beyond (Vol. 3, pp. 401-418). Springer. https://doi. org/10.1007/978-3-030-51237-8

Barrientos, A. (2004). Latin America: Towards a liberalinformal welfare regime. In I. Gough, G. Wood, A. Barrientos, P. Bevan, P. Davis, \& G. Room (Eds.), Insecurity and welfare regimes in Asia, Africa and Latin America: Social policy in development contexts (pp. 121-168). Cambridge University Press.

Borjas, G. J. (1998). Immigration and welfare magnets. Journal of Labor Economics, 17(4), 607-637.

Çağlar, A. (2004). "Citizenship light": Transnational ties, multiple rules of membership, and the "pink card." In J. Freedmann \& S. Randeria (Eds), Worlds on the move: Globalisation, migration and cultural security (Vol. 6, pp. 273-291). I.B. Tauris.

Castles, F. G. (1999). Comparative public policy: Patterns of post-war transformation. Edward Elgar.

Collyer, M. (Ed.). (2013). Emigration nations: Policies and ideologies of emigrant engagement. Palgrave.

Deacon, B., \& Nita, S. (2013). Regional social integration and free movement across borders: The role of social policy in enabling and preventing access to social entitlements by cross-border movers. European Union and Southern Africa compared. Regions and Cohesion, 3(1), 32-61.

Delano, A. (2009). From limited to active engagement: Mexico's emigration policies from a foreign policy perspective (2000-2006). International Migration Review, 43(4), 764-814.

Delano, A. (2018). From here and there: Diaspora policies, integration, and social rights beyond borders. Oxford University Press.

Driscoll de Alvarado, B. (2003). The 10\% solution: Bracero program savings' account controversy. ReVista: Harvard Review of Latin America. https://revista.drclas. harvard.edu/the-10-solution

Esping-Andersen, G. (1990). The three worlds of welfare capitalism. Polity Press.

Faist, T. (2019). The transnationalized social question: Migration and the politics of social inequalities in the twenty-first century. Oxford University Press. 
Faist, T., \& Bilecen, B. (2014). Social inequalities through the lens of social protection: Notes on the transnational social question. Population, Space and Place, 21(3), 282-293. https://doi.org/10.1002/psp. 1879

Fenwick, C. (2019). The political economy of immigration and welfare state effort: Evidence from Europe. European Political Science Review, 11(3), 357-375.

Ferrera, M. (1996). The "Southern model" of welfare in social Europe. Journal of European Social Policy, 6(1), 17-37.

Ferrera, M., Hemerijck, A., \& Rhodes, M. (2000). Recasting European welfare states for the 21st century. European Review, 8(3), 427-446.

Frank, R., Palma-Coca, O., Rauda-Esquivel, J., OlaizFernández, G., Díaz-Olavarrieta, C., \& AcevedoGarcía, D. (2009). The relationship between remittances and health care provision in Mexico. American Journal of Public Health, 99(7), 1227-1231.

Gamlen, A. J. (2019). Human geopolitics: States, emigrants, and the rise of diaspora institutions. Oxford University Press.

González Gutíerrez, C. (2003). La diplomacia de México ante su diáspora [Mexico's diplomacy towards its diaspora]. In R. Fernández de Castro (Ed.), En la frontera del imperio [On the border of the Empire] (pp. 165-175). Ariel.

Hemerijck, A. (2006). Recalibrating Europe's semisovereign welfare states (WZB Discussion Paper). Wissenschaftszentrum Berlin für Sozialforschung. http://hdl.handle.net/10419/43981

Kureková, L. (2013). Welfare systems as emigration factor: Evidence from the new accession states. JCMS: Journal of Common Market Studies, 51(4), 721-739.

Lafleur, J.-M. (2013). Transnational politics and the state: The external voting right of diasporas. Routledge.

Lafleur, J.-M., \& Mescoli, E. (2018). Creating undocumented EU migrants through welfare: A conceptualization of undeserving and precarious citizenship. Sociology, 52(3), 480-496.

Maas, W. (2007). Creating European citizens. Rowman \& Littlefield Publishers.

Marshall, T. H. (1964). Class, citizenship, and social development: Essays. Doubleday.

Martínez Franzoni, J. (2018). Quest for universal social policy in the South: Actors, ideas, and architectures. Cambridge University Press.

McFadden, S. W. (2019). German citizenship law and the Turkish diaspora. German Law Journal, 20(1), 72-88.

Mingot, E. S., \& Mazzucato, V. (2017). Mobile populations in immobile welfare systems: A typology of institutions providing social welfare and protection within a mobility framework. The European Journal of Development Research, 29(4), 787-805.

OECD. (2011). Age dataset, covering all ages of emigrant population aged $15+$ across 58 destinations, reference year 2010. https://data.oecd.org/pop/ population

Office for the Turks Abroad and Related Communities.
(2022). Sosyal Hizmetler [Social services]. https:// www.ytb.gov.tr/soru-cevap/sosyal-hizmetler

Özel, I. D., \& Parrado, S. (2020). Varieties of regulatory welfare regimes in middle-income countries: A comparative analysis of Brazil, Mexico, and Turkey. The Annals of the American Academy of Political and Social Science, 691(1), 223-242. https://doi.org/ $10.1177 / 0002716220965884$

Pampel, F. C., \& Williamson, J. B. (1989). Age, class, politics, and the welfare state. Cambridge University Press.

Pennings, F., \& Seeleib-Kaiser, M. (Eds.). (2018). EU citizenship and social rights: Entitlements and impediments to accessing welfare. Edward Elgar Publishing.

Pierson, P. (1994). Dismantling the welfare state? Reagan, Thatcher and the politics of retrenchment. Cambridge University Press.

Sirkeci, I. (2003). Migration, ethnicity and conflict: The environment of insecurity and Turkish Kurdish international migration [Doctoral dissertation, University of Sheffield]. https://etheses.whiterose.ac.uk/6007

Smith, R. C., Waisanen, D. J., \& Barbosa, G. Y. (2020). Immigration and strategic public health communication: Lessons from the transnational seguro popular project. Routledge.

Soysal, Y. (1994). Limits of citizenship: Migrants and postnational membership in Europe. Chicago University Press.

Stark, O., \& Bloom, D. E. (1985). The new economics of labor migration. The American Economic Review, 75(2), 173-178.

Turkish-Islamic Union for Religious Affairs. (2009). DітіB Sosyal ve Aile Danışmanlığı Hattı Hizmete Girdi [DITIB social and family counselling services have started]. https://www.ditib.de/detail2.php?id=321\&lang=en

Umpierrez de Reguero, S. A., Yener-Roderburg, I. Ö., \& Cartagena, V. (2021). Political regimes and external voting rights: A cross-national comparison. Frontiers in Political Science, 3(10). https://doi.org/10.3389/ fpos.2021.636734

Van Kersbergen, K. (2002). The politics of welfare state reform. Swiss Political Science Review, 8(2). https:// doi.org/10.1002/j.1662-6370.2002.tb00392.x

Vargas-Bustamante, A. V., Ojeda, G., \& Castañeda, X. (2008). Willingness to pay for cross-border health insurance between the United States and Mexico. Health Affairs, 27(1), 169-178.

Vargas-Bustamante, A., Laugesen, M., Mabel, M., \& Rosenau, P. (2012). United States-Mexico cross-border health insurance initiatives: Salud Migrante and Medicare in Mexico. Revista Panamericana de Salud Pública, 31(1), 74-80.

Wilensky, H. L., \& Lebeaux, C. N. (1965). Industrial society and social welfare: The impact of industrialization on the supply and organization of social welfare services in the United States. Free Press.

Wood, G., \& Gough, I. (2006). A comparative welfare regime approach to global social policy. World Devel- 
opment, 34(10), 1696-1712.

Yanasmayan, Z., \& Kaşlı, Z. (2019). Reading diasporic engagements through the lens of citizenship: Turkey as a test case. Political Geography, 70, 24-33.

Yener-Roderburg, I. Ö. (2020). Party organizations across borders: Top-down satellites and bottom-up alliances. The case of AKP and HDP in Germany. In T. Kernalegenn \& E. van Haute (Eds.), Political parties abroad (pp. 218-237). Routledge.

\section{About the Authors}

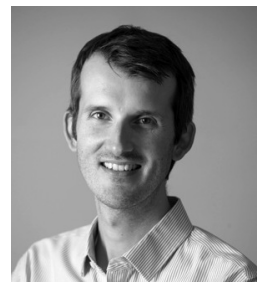

Jean-Michel Lafleur is a research professor at the University of Liège, associate director of CEDEM, and a senior research associate at the Belgian Fund for Scientific Research (FRS-FNRS). He is also a lecturer in SciencesPo Paris. Jean-Michel's areas of expertise are the transnational dimension of contemporary migration, EU mobility, social protection, and the political participation of immigrants. He is the P.I. of the European Research Council (ERC) project Migration and Transnational Social Protection in (Post)Crisis Europe. Recently, Jean-Michel was appointed as the coordinator of the IMISCOE research network for the period 2022-2026. https://orcid.org/0000-0002-8954-5167

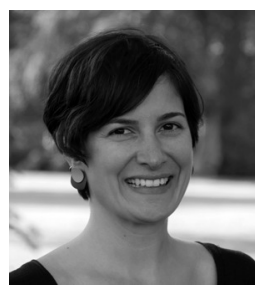

Inci Öykü Yener-Roderburg is a PhD candidate at the University of Duisburg-Essen (Germany) and the University of Strasbourg (France) focusing on diasporas' political mobilisations for "homeland" political parties through emigrant enfranchisement. Inci also contributed to the ERC project Migration, Transnationalism and Social Protection in Europe, led by Jean-Michel Lafleur (University of Liège, Belgium). She currently works as a researcher and lecturer at the University of Duisburg-Essen, and as a research fellow at TU Dortmund in the Department of Sociology of Migration. https://orcid.org/ 0000-0001-9698-1058 